\title{
TOPOCLIMATIC DIFFERENTIATION OF THE AREA OF THE SŁOWIŃSKI NATIONAL PARK, NORTHERN POLAND
}

\author{
LesZeK Kolendowicz, Ewa BeDnorz \\ Adam Mickiewicz University, Institute of Physical Geography and Environmental Planning, \\ Department of Climatology \\ Manuscript received January 21, 2010 \\ Revised version March 12, 2010
}

Kolendowicz L., BeDnorz E., 2010. Topoclimatic differentiation of the area of the Słowiński National Park, northern Poland. Quaestiones Geographicae 29(1), Adam Mickiewicz University Press, Poznań 2010, pp. 49-56, Figs 1. ISBN 978-83-232-2136-4. ISSN 0137-477X. DOI: 10.2478/v10117-010-0005-6

\begin{abstract}
The primary objective of the study was to elaborate a synthetic topoclimatic map of the area of the Słowiński National Park (SNP). The spatial scopes of individual types of topoclimate were distinguished using the method proposed by Paszyński (1999). Pursuant to this method, the topoclimatic classification - and subsequently topoclimatic charting - is performed on the basis of an analysis of the exchange of energy between the atmosphere and its base. The research conducted allowed us to determine that the SNP contains 12 types of local climate, and also to designate the spatial scopes thereof.
\end{abstract}

KEYWORDS: topoclimate, radiation balance, Słowiński National Park, Baltic Sea coast

Leszek Kolendowicz, Ewa Bednorz, Department of Climatology, Institute of Physical Geography and Environmental Planning, Adam Mickiewicz University, Dzieggielowa 27, 61-680 Poznań, Poland, leszko@amu.edu.pl, ewabedno@amu.edu.pl

\section{Introduction}

The area of the Słowiński National Park (SNP), located on the Słowiński Coast of the Baltic Sea, is a particularly valuable fragment of the Polish biosphere, which due to its unique natural values has been classified by UNESCO as a World Biosphere Reservation and also included in the network of wetlands covered by the RAMSAR Convention. To date, a considerable part of the elements of the Park's biosphere has been researched, and the results published. One of the elements that has not yet undergone a complete scientific analysis is the ground layer of the troposphere, in which specific types of topoclimate develop.
Numerous climatologic research projects have been conducted on the area of the SNP. However, the majority of research has been carried out on a small fragment of the Park's area, situated in its northern part, which covers the central part of the Łeba Sandbar. This work has resulted in a precise description of the thermal and humidity conditions of selected types of ecosystems (Kolendowicz, 2002; Rabski, 1987), and of the daily variability of wind velocity and direction (Bogucki, 1994; Tamulewicz, 2002). The variability of the cooling magnitude of air has also been determined (Medzińska, 1991). Furthermore, an analysis was performed of the synoptic determinants of strong precipitation during the summer period (Kolendowicz et al., 2004). The problem of the climate of 
the Park's area on a mesoclimatic scale has been touched upon by Rabski (1992). Hitherto, research facilitating the distinguishment of specific types of topoclimate has also included the area of the Sandbar (Bednorz et al., 2001).

The topoclimate is understood to mean the climate of a given local area or of a very small area (Thornthwaite, 1953, 1958). It develops under the impact of local (area-specific) factors, and is a function of the topographic profile, land coverage, vegetation, and water and soil relations, while at the same time it influences the development of these elements. In the climatologic hierarchy, the topoclimate occupies a position between the mesoclimate and the microclimate.

We may state that the impact of the Earth's surface on the atmosphere is limited, when analysed on a daily scale, to its boundary layer. In turn, the greatest differentiation of meteorological elements, which results from significant values of streams of momentum, mass and heat, occurs in the lower part of this layer, known as the ground layer. Thus, individual types of topoclimate originate under the influence of the diverse action of the active surface on the atmospheric layer located directly beneath it, which is characterised by a variable daily thickness, totalling a few dozen metres during the day and a few metres at night (Paszyński, 1999).

\section{The aim of the study and research methods}

The primary objective of the study was to elaborate a synthetic topoclimatic map of the area of SNP. Topoclimatic research is rendered difficult by the necessity of conducting field observations using specialist measurement equipment or basing on the cartographic analysis of areas - in the broadest meaning of the term. The main problem concerns attempts at presenting climatologic reality on a four-dimensional plane, which in addition to the three spatial dimensions takes into consideration the variability of climatic phenomena over time (Błażejczyk, 2001).

The map outlining the scope of selected types of topoclimate presented in the study( Fig. 1) is intended to broaden our climatologic knowledge and fill the gap in scientific literature concerning the SNP, with its unique natural features.

Methodological achievements regarding detailed climate charting are relatively abundant. Attempts at determining the topoclimate of specific townships or larger fragments of the Earth's surface are rather numerous - both in Poland and abroad. As regards Polish literature describing the topoclimate of selected townships, particularly noteworthy are - among others - the works of Jankowiak \& Parczewski (1978) and Błażejczyk (1984). Fragments of the territory of Poland have been the subject of topoclimatic studies carried out, among others, by Paszyński (1966), Skoczek (1970), Grzybowski (1983, 1986a, 1986b), Obrębska-Starklowa (1980), Błażejczyk (1992), Tamulewicz (1997), Bednorz et al. (2001) and Kicińska et al. (2001).

Usually, works concerning the issue in question for the area of Poland take into consideration

LEGEND to Fig. 1

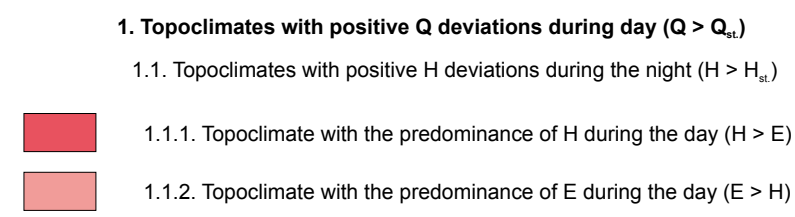

2. Topoclimates with average values of $\mathbf{Q}$ during the day $\left(\mathbf{Q}=\mathbf{Q}_{\mathrm{st}}\right)$
2.1. Topoclimates with positive $H$ deviations during the night $\left(H>H_{s t}\right)$

2.1.1. Topoclimate with the predominance of $\mathrm{H}$ during the day $(H>E)$

2.2. Topoclimates with average values of $\mathrm{H}$ during the night $\left(\mathrm{H}=\mathrm{H}_{\mathrm{st}}\right)$

2.2.1. Topoclimate with the predominance of $\mathrm{H}$ during the day $(\mathrm{H}>\mathrm{E})$ 2.2.2. Topoclimate with the predominance of $E$ during the day $(E>H)$

2.3. Topoclimates with negative $\mathrm{H}$ deviations during the nigt $\left(\mathrm{H}<\mathrm{H}_{\mathrm{st}}\right)$

2.3.1. Topoclimate with the predominance of $\mathrm{H}$ during the night $(\mathrm{H}>\mathrm{G})$

2.3.2. Topoclimate with the predominance of $G$ during the night $G>H$ ))

3. Topoclimates with negative $Q$ deviations during the day $\left(Q<Q_{s t}\right)$

3.1. Topoclimate with positive $\mathrm{H}$ deviations during the night $\left(\mathrm{H}>\mathrm{H}_{\mathrm{st}}\right)$

3.1.1 Topoclimate with the predominance of $\mathrm{H}$ during the day $(\mathrm{H}>\mathrm{E})$

3.1.2. Topoclimate with the predominance of $E$ during the day $(E>H)$

3.2. Topoclimates with negative $H$ deviations during the night $\left(H<H_{s t}\right)$

4. Topoclimate with positive $\mathrm{H}$ values during the day and negative $\mathrm{H}$ values during the night

6. Topoclimate with the occurrence of $A$ 


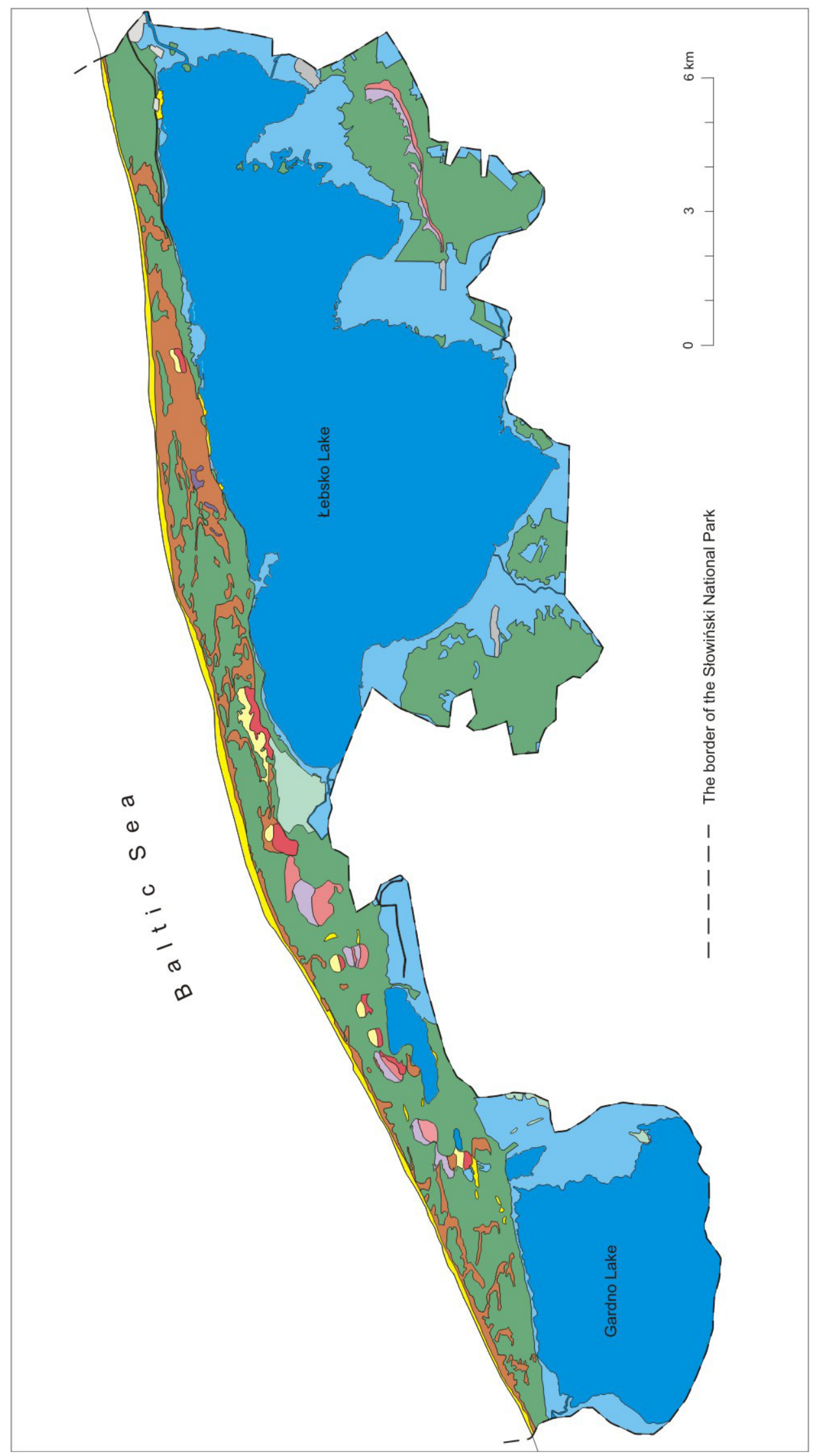

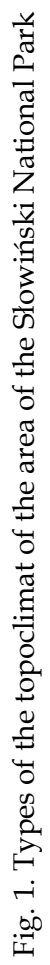


genetic criteria. The majority of existing topoclimatic studies are based on the method proposed by Paszyński $(1980,1999)$, which takes into consideration the exchange of energy between the active surface and the atmosphere.

Amongst methods that could be used as the basis for elaborating topoclimatic maps, one may mention - in addition to Paszyński's method $(1980,1999)$ - the proposal put forward by Kluge (1980), which makes it possible to use derived formulae that take into consideration geographical coordinates and height above sea level in order to determine the average temperature in a warm or cold half-year on a grid of parallels (every $0.5^{\prime}$ ) and meridians (every $7.5^{\prime}$ ). The fact that the height above sea level could be taken into account has enabled the author to classify the elaborated air temperature distribution maps as topoclimatic maps.

Grzybowski (1990) has proposed a method of determining topoclimate types based on the structure of the thermal balance of the active surface, distinguishing the types, grades and variations of the topoclimate. The proposed distinguishment has been based on the following: the differentiation of the radiation balance, its structure, and the properties of the active surface.

The final proposal centres on the concept of a survey topoclimatic map as authored by Błażejczyk (2001), which is to result in a map on a scale of 1:200 000 with a primary area of $1 \times 1 \mathrm{~km}$, elaborated using GIS techniques and procedures.

In foreign literature, examples of survey topoclimatic or biotopoclimatic maps covering the area of entire countries include maps of Romania (Bogdan et al., 1977), the Czech Republic (Quitt, 1992) and Germany (Jendritzky, 1990).

In order to determine the spatial scope of individual types of topoclimate on the area of the SNP, the authors of the present study made use of the method proposed by Paszyński (1999).

Pursuant to this method, the topoclimatic classification - and subsequently topoclimatic charting - is performed on the basis of an analysis of the exchange of energy between the atmosphere and its base. One of the assumptions is a comparison of the values of individual energy streams with values characteristic of the standard area (a flat area with an unobstructed horizon, covered with grass), and an analysis of deviations thereof from these values. Comparisons are made for conditions existing during the predominance of radiation weather, when the absolute value of energy streams and the spatial differentiation of the action of the base on the ground layer are greatest. In addition, the main features of the structure of the energy balance are taken into consideration.

Due to the fundamental differences in the structure of the balance between the day-time and night-time, during the initial charting phase separate maps are elaborated for the day and night; consequently, two divisions of the types of energy exchange within the 24-hour period for the analysed area could be obtained. The final synthetic classification of topoclimate types is achieved by the elimination of less significant distinguishments. In consequence, we arrive at a division of six topoclimate types (acc. to Paszyński's (1999) types):

1. Topoclimates with positive $Q$ deviations during the day $(Q>Q s t)$

1.1. Topoclimates with positive $H$ deviations during the night $(H>H s t)$

1.1.1. Topoclimate with the predominance of $H$ during the day $(H>E)$,

1.1.2. Topoclimate with the predominance of $E$ during the day $(E>H)$,

1.2. Topoclimates with negative $H$ deviations during the night $(H<H s t)$

1.2. 1. Topoclimate with the predominance of $H$ during the day $(H>E)$,

1.2.2. Topoclimate with the predominance of $E$ during the day $(E>H)$,

2. Topoclimates with average values of $Q$ during the day $(Q=Q s t)$

2.1. Topoclimates with positive $H$ deviations during the night $(H>H s t)$

2.1.1. Topoclimate with the predominance of $H$ during the day $(H>E)$,

2.1.2. Topoclimate with the predominance of $E$ during the day $(E>H)$,

2.2. Topoclimates with average values of $H$ during the night $(H=H s t)$

2.2.1. Topoclimate with the predominance of $H$ during the day $(H>E)$,

2.2.2. Topoclimate with the predominance of $E$ during the day $(E>H)$, 
2.3. Topoclimates with negative $H$ deviations during the night $(H<H s t)$

2.3.1. Topoclimate with the predominance of $H$ during the night $(H>G)$,

2.3.2. Topoclimate with the predominance of $G$ during the night $(G>H)$,

3. Topoclimates with negative $Q$ deviations during the day $(Q<Q s t)$

3.1. Topoclimates with positive $H$ deviations during the night $(H>H s t)$

3.1.1. Topoclimate with the predominance of $H$ during the day $(H>E)$,

3.1.2. Topoclimate with the predominance of $E$ during the day $(E>H)$,

3.2. Topoclimates with negative $H$ deviations during the night $(H<H s t)$,

4. Topoclimate with positive $H$ values during the day and negative $H$ values during the night,

5. Topoclimate with positive $E$ values during the night,

6. Topoclimate with the occurrence of $A$.

Where:

$Q$ - the shortwave and the long wave radiation balance between the Earth's surface and the atmosphere,

$H$ - the stream of the sensible heat,

$E$ - the stream of the latent heat,

$G$ - the stream of the heat in the soil,

$A$ - the anthropogenic stream.

In the present studies, topographic maps of the area of the SNP, drawn up on a scale of 1:25,000, were used as the working base.

Topoclimate type 1 refers to areas that due to their favourable exposure (southerly) or small albedo values are warmer during the day than the standard surface. Topoclimate type 2 is typical of areas with average exposure and albedo values (flat areas or ones with an easterly or westerly exposure), whereas type 3 is characteristic of areas that are cooler during the day than the standard surface due to their unfavourable exposure, high albedo values, or the obstruction of the horizon. The further division into topoclimate subtypes takes into consideration values of the sensible heat stream $(H)$ during the nighttime. An $H$ stream greater than standard designates areas that are warmer than standard for a specific fragment of the 24-hour period, where losses of longwave radiation are compensated by the influx of sensible heat from the atmosphere. These are the upper parts of slopes, which are warm during the night. An $H$ stream close to standard values is typical of flat areas located above valley beds, whereas an $H$ stream lower than standard is characteristic of depressions, where there exist conditions for the development of marginal lakes of cool air.

A further division into subtypes is based on the Bowen's relation (relation of $H$ to $E$ ) during the day. Areas for which the Bowen's relation $(H / E)$ is greater than one are ones with small evapotranspiration values, relatively dry, with sparse vegetation or totally devoid of vegetation. In the event that $E$ stream value is greater than the $H$ value, the area is characterised by relatively intensive evapotranspiration caused by lush vegetation or the wetness of land. For depressions $(H<H s t)$ with average values of the radiation balance $(Q)$, the division into subtypes takes into consideration the relation of the stream of sensible heat to the stream of heat in the base. For $H>G$, compensation for heat losses during the night occurs thanks to the turbulent stream of sensible heat. For $H<G$, in turn, heat is supplemented thanks to the energy gathered in the tall vegetation. A topoclimate with positive values of the turbulent stream of sensible heat during the day (the influx of heat occurs to the base) and negative values during the night (heat from the base warms the atmosphere thanks to the $H$ stream) is characteristic of water areas (Paszyński et al., 1999).

\section{Research results}

In accordance with the physical-geographical division of Poland introduced by Kondracki (1998), the SNP constitutes an element of the Słowiński Coast mesoregion. This mesoregion is the most northerly part of the Koszalin Littoral, which forms a part of the Southern Baltic Littoral region. The area of the Park covers a part of the Gardno-Łeba Lowland and the Łeba Sandbar. The southern part of the Park covers 
the end moraines of the Gardno-Łeba phase of the final glaciation, with the highest culmination being $115 \mathrm{~m}$ above sea level. (the Rowokół hill). The Park's terrain includes a few lakes, among others Łebsko, Gardno, Dołgie Wielkie, Dołgie Małe and Smołdzińskie. The area in question is drained by seven rivers. The largest of these are the Łeba, which flows through the Łebsko Lake, and the Łupawa, which flows into the Gardno Lake. Water occupies more than $30 \%$ of the area of the SNP.

The analysed area is covered by a mosaic of ecosystems. Forest ecosystems comprise nearly $20 \%$ of the area, and of these $80 \%$ are woods in which Scots pine is predominant (more than $70 \%$ ). Apart from pine, silver birch accounts for more than $12 \%$, black alder for nearly $6 \%$, downy birch for $2.5 \%$, and Norway spruce and European black pine together account for more than $2 \%$ of the area. The remaining species (European beech, English oak, etc.) have a total share in the forest stand of approximately $1 \%$.

Conditions existing in the Park are conducive to the development of peat-bogs. In particular, low-lying peat-bogs flourish around lakes and water-courses, with their high levels of underground water. What is more, the prevailing conditions support the development of high-lying and transient peat-bogs.

Meadows are present near the Łebsko and Gardno Lakes on the Gardno-Łeba Lowland.

The activity of the sea and wind has led to the creation of many generations of crescent-shaped dunes on marine barrier sands, transformed into curved dunes and inselberg and deflation-type forms. In the central part of the Łeba Sandbar there was formed a dune field with a length of approximately $5 \mathrm{~km}$ and width of $1 \mathrm{~km}$, originating from crescent-shaped dunes moving with a speed of $2-10 \mathrm{~m} /$ year.

A detailed analysis of topographic maps on a scale of 1:25,000, which covered the entire area of the SNP, supplemented by field studies, formed the basis for determining the spatial scopes of the topoclimate types distinguished in Paszyński's classification (1999).

The area of flat beaches covered with light sandy formation, subject to direct exposure to the sea on a topoclimatic scale, has been classified as belonging to the topoclimate type desig- nated 2.2.1. This type refers to areas with average values of the radiation balance $(Q)$ and devoid of vegetation.

The majority of areas with a somewhat uniform topographic profile, with the exception of river valley beds and areas adjacent to lake shores, covered with forests or forest formations, are typical of the topoclimate type designated 2.2.2. Here, the values of the radiation balance $(Q)$ are average during the day, as are the values of the turbulent stream of sensible heat during the night, with the turbulent stream of latent heat (E) (considerable evaporation) prevailing over the stream of sensible heat $(H)$ during the day. Higher land forms with clearly marked slopes and a southerly exposure, covered with vegetation, are typical of the topoclimate type designated 1.1.2. This refers to areas with positive deviations of the radiation balance (areas warmer than standard during the day) and positive deviations of the $H$ stream during the night, with the $E$ stream prevailing over the $H$ stream during the day. Similar forms, however without vegetation (southern, clearly marked dune slopes), are subject to the topoclimate type designated 1.1.1. This topoclimate type is characterised by positive deviations of the radiation balance $(Q)$ during the day, positive deviations of the turbulent stream of sensible heat during the night, and a positive Bowen's relation during the day (prevalence of the $H$ stream over the E stream).

Dune areas devoid of vegetation, with the exception of the clearly marked deflations and slopes with a northerly or southerly exposure, belong to the topoclimate type designated 2.1.1. They are characterised by average values of the radiation balance (due to the considerable albedo values following from the light colour of the dune sand), positive deviations of the $H$ stream during the night and the predominance of the $H$ stream over the $E$ stream during the day.

Areas located in the immediate vicinity of lakes and in water-course valleys, covered with grassy vegetation or reeds, are included in the topoclimate type designated 2.3.1. These areas are flat and wet, situated in depressions with an unobstructed horizon, with average values of the radiation balance and negative deviations of the $H$ stream during the night. Heat lost through radiation during the night is supplemented by the 
influx of heat from the atmosphere. If the aforementioned areas are forested, the topoclimate type changes to 2.3.2. Heat losses on the active surface during the night are supplemented with heat gathered in the vegetation (the $G$ stream is greater than the $H$ stream).

Areas of undrained depressions (deflationtype depressions in dune fields), devoid of vegetation, are characterised by topoclimate type 3.2. They are distinguished by a negative radiation balance $(Q)$ during the day, this due to the partial obstruction of the horizon, and negative deviations of the value of the turbulent stream of sensible heat $(H)$ during the night (marginal lakes of cool air gather in this time).

The type 4 topoclimate covers areas of water reservoirs, while the type 6 topoclimate covers areas on which the anthropogenic heat stream $A$ occurs.

\section{Conclusions and discussion}

The majority of the area of the SNP is covered by topoclimate type 2 , with average values of the radiation balance during the day. This includes both areas with vegetation and considerable areas of dunes made of light eolian sand, and the beach area and terrain covered with relatively low meadow vegetation, located in water-course valleys and on lake shores. Furthermore, significant in terms of the surface occupied are the water areas, which comprise more than $30 \%$ of the Park's area. They are covered by topoclimate type 4 and are characterised by the reversal of directions of the turbulent stream of sensible heat during the day-time and night-time in relation to land areas. This is directly connected with the difference in thermal capacity between water and land (Paszyński et al., 1999). Areas with a small surface are covered both by topoclimate type 1 , with positive deviations of the radiation balance during the day (slopes with a southerly exposure), and type 3, which is characteristic of undrained depressions, in which marginal lakes of cool air gather during the night. Only very small fragments of the Park are covered by a climate with a stream of anthropogenic heat $(A)$. These are small areas in the eastern part of the SNP.
The research results obtained, in the form of designated scopes of topoclimate types in accordance with Paszyński's classification (1999), are concurrent with the results of work carried out by other authors - Tamulewicz (1997), Bednorz et al. (2001). The transparency and clarity of criteria adopted in the method ensure that it is an excellent tool for designating the spatial scopes of selected types of topoclimate on a scale from $1: 20,000$ to $1: 50,000$.

\section{Acknowledgements}

Authors of the paper would like to thank Mrs mgr Hanna Forycka-Ławniczak for preparing the topoclimatic map of the area of the Słowiński National Park.

\section{References}

Bednorz E., Kolendowicz L. \& Szyga-Pluta K., 2001. Typy topoklimatu Słowińskiego Parku Narodowego. In: M. Kuchcik (ed.), Wspótczesne Badania Topoklimatyczne, Dokumentacja Geograficzna 23, 19-32.

BŁAŻEJCZYK K., 1984. Metody kartowania topoklimatycznego uzdrowisk. Problemy bioklimatologii uzdrowiskowej, cz V. Dokumentacja Geograficzna 1-2: 89-102.

BŁAŻEJCZYK K., 1992. Wpływ urbanizacji na lokalne warunki bioklimatyczne. Zeszyty IGiPZ PAN 6: 15-27.

BŁAŻEJCZYK K., 2001. Koncepcja przeglądowej mapy topoklimatycznej Polski. In: M. Kuchcik (ed.), Wspótczesne Badania Topoklimatyczne, Dokumentacja Geograficzna 23, 131-141.

Bogdan O., Teodorenau E., Mihai E., Neamu G., Doneaud A., Patache J., Cazacu G., Dinca S., Miha J. \& Patrichi S., 1977. Harta toppoklimata. In: Atlasul Republicii Sacialiste Romania, Academiei Republicii Socialiste Romania, Bukareszt.

BoguCKI J., 1994. Dobowa zmienność kierunku wiatru na Mierzei Łebskiej. Badania Fizjograficzne nad Polska Zachodnia, Seria A - Geografia Fizyczna XLV: 5-23.

GrzybowsKi J., 1983. Wyróżnianie i klasyfikacja jednostek przestrzennych wymiany energii na powierzchni czynnej na przykładzie Kotliny Biebrzańskiej. Przegląd Geograficzny 55: 2.

GrzYbowSKI J., 1986a. Mapa wymiany energii między atmosferą a podłożem jako podstawa analizy funkcjonowania środowiska geograficznego. Przegląd Geograficzny 58: 1 .

GRZYвOWSкI J., 1986b. L'influence des proprietes physiques de la surface active suc la repartitions des topoclimats. International Symposium on topoclimatology and its applications. Proceedings of the conference Liege, Mont Rigi, Belgium, March 14-16, 1985. 
GrZYbowsKi J., 1990. Próba wydzielenia typów topoklimatu na obszarze Polski. In: J. Grzybowski (ed.), Problemy wspótczesnej topoklimatologii, Conference Papers 4: 34-40.

JankowiaK J. \& PARCZeWsKi W., 1978. Bioklimat uzdrowisk polskich. Wyd. Komunikacji i Łączności, Warszawa.

JENDRITZKY G., 1990. Das Bioklima In der Bundesrepublik Deutschland. In: H. Schimer. (ed.) Methodik zur raumlichen Bewertung der thermischen Komponente in Bioklima des Menschen. Akademie Raumforschung u. Landesplannung 114, Hanover.

KicińsKa B., Olszewski K. \& ŻMudzKa E., 2001. Uwagi o wykorzystaniu klasyfikacji J.Paszyńskiego do kartowania topoklimatycznego (z doświadczeń Zakładu Klimatologii Uniwersytetu Warszawskiego). In: M. Kuchcik (ed.), Wspótczesne Badania Topoklimatyczne, Dokumentacja Geograficzna 23, 143-152.

KLUGE M., 1980. Metoda konstruowania map topoklimatrycznych w skali przeglądowej i jej zastosowania do regionalizacji fizyczno-geograficznej. Metody opracowań topoklimatycznych. Dokumentacja Geograficzna 3: 36-49.

KolENDOWICZ L., 2002. Zróżnicowanie temperatury, wilgotności względnej oraz wielkości ochładzającej powietrza w Słowińskim Parku Narodowym. Badania Fizjograficzne nad Polska Zachodnia, Seria A - Geografia Fizyczna 53: 83-93.

Kolendowicz L., Bednorz E. \& Szyga-Pluta K., 2004. Analysis of chosen cases of high daily rainfall at the local station of Climatology Department Adam Mickiewicz University in Poznań in Słowiński National Park. Quaestiones Geographicae 23,. 49-54.

MEDZIŃSKA M., 1991. Charakterystyka wielkości ochładzającej powietrza w profilu Mierzei Łebskiej w okresie letnim 1988. Badania Fizjograficzne nad Polska Zachodnia, Seria A - Geografia Fizyczna 37: 73-89.

OBRĘBSKA-STARKLOWA B., 1980. Z zagadnień metodycznych kartowania stosunków klimatycznych w Beskidach w ska- li szczegółowej. Metody opracowań topoklimatycznych. Dokumentacja Geograficzna 3: 29-35.

PAsZYŃSKI J., 1966. Klimat okolic Pińczowa. In: Studia geograficzne w powiecie pińczowskim. Prace Geograficzne 47: 89-114.

PASZYŃSKI J., 1980. Metody sporządzania map topoklimatycznych. Metody opracowań topoklimatycznych. Dokumentacja Geograficzna 3: 13-28.

PASZYŃSKI J., MiARA K. \& SKOCZEK J., 1999. Wymiana energii między atmosferą a podłożem jako podstawa kartowania topoklimatycznego. Dokumentacja Geograficzna 14, Warszawa.

QuiTT E., 1992. Topoklimatische Typen In Mitteleuropa. In: Atlas Ost und Sudeuropa, N 1.3-M1. Osterreichisches Ostund Sudeuropa Institut, Vien.

RABSKI K., 1987. Wstępna charakterystyka termicznowilgotnościowa Mierzei Łebskiej. Badania Fizjograficzne nad Polską Zachodnia, Seria A - Geografia Fizyczna 42: 191-205.

RABSKI K., 1992. Mezoklimatyczne tło obszaru Słowińskiego Parku Narodowego. Parki Narodowe i Rezerwaty Przyrody 11(1).

TAMuleWICZ J., 1997. Pogoda i klimat Ziemi. In: A Kostrzewski (ed.), Wielka Encyklopedia Geografii Świata. Wydawnictwo Kurpisz, Poznań.

Tamulewicz J., 2001. Prędkość wiatru w sezonie letnim w Słowińskim Parku Narodowym w obrębie Mierzei Łebskiej. Badania Fizjograficzne nad Polską Zachodnia, Seria A - Geografia Fizyczna 52, 149-159.

ThornthwWAite C.W., 1953. Topoclimatology. Proceedings of the Toronto Meteorologica Conference: 227-232.

ThornthwwaIte C.W., 1958. Introduction a la climatologie de la zone aride. In: Climatology and microclimatology. Proceedings of the Canberra Symposium, Arid Zone Research, XI, UNESCO: 23-31. 